\title{
Value Added Tax and Inflation in Ethiopia: Evidence from Granger Causality Analysis
}

\author{
Isubalew Daba Ayana \\ Ph.D. Fellow, Department of Economics, Wollega University, Nekemte, Ethiopia
}

\begin{abstract}
The study investigates the causal relationship between Value added tax and inflation in Ethiopia using quarterly time-series data from 2004 to 2014. Data for this study was sourced from the National bank of Ethiopia (NBE) and the Central Statistical Agency of Ethiopia (CSA). The data is verified for unit root using the Augmented Dickey-Fuller (ADF) test and the Philips-Perron (PP) unit root test, and the result confirms that variables of the study are stationary in their first differences. The Pairwise Granger causality analysis revealed that VAT Granger causes inflation. The result from the VECM has shown that the speed of adjustment is negative 0.4790. This result infers that 47.9 percent of disturbances are corrected each quarter in the inflation (LOGCPI) equation. The sign of error correction term when VAT is dependent variable is negative but not significant at $5 \%$ level of significance ( -1.67359 and 0.1058 , error correction term and t-probability respectively) showing only unidirectional causality running from Value added tax(VAT) to the price level in Ethiopia in long run. The coefficient of VAT from Wald coefficient restriction tests is different from zero indicating the causality from VAT to inflation in Ethiopia in the short run. This also indicates that causality running from lagged variables of Value added tax to the lagged level of price. The study concluded that there is a casual relationship between VAT and inflation in Ethiopia in both the short run and the long run during the period under investigation. The policy implication is that a very comprehensive post VAT cost-benefit analysis needs to be carried out in the process of public revenue generation. It follows that attention should be given to social welfare and communal desire alongside public income generation.
\end{abstract}

Keywords: VAT, Inflation, Granger Causality Analysis, Ethiopia

DOI: $10.7176 /$ RJFA/11-21-03

Publication date: November $30^{\text {th }} 2020$

\section{Introduction}

Rising domestic revenue has a paramount significance for any country of the world to overcome economic, social, and political hitches of the societies. In this globalized twenty-first century, almost all scholars have the same view that VAT has a significant contribution to the growth of a country. For instance, Alemu (2011), in his scholarly contribution, revealed that value-added tax is contributing to Ethiopian economic development and social spending. According to Adereti et al. (2011), who studied value-added tax and economic growth of Nigeria for the period 1994 - 2010, the correlation between VAT Revenue and GDP is positive and significant. Bogetic and Hassan (1993) publicized that by introducing VAT in 1983, Indonesia had elevated the ratio of VAT revenue to GDP to 4.5 percent within five years in 1988 .

In Ethiopia, the conception of VAT is comparatively a recent phenomenon having an age of fewer than two decades as it was adopted in the country after 50 years of its implementation in France in 1954. The adoption of VAT in Ethiopia starts from January 1, 2003, when it was declared by proclamation no. 285/2002. This makes Ethiopia the late country that introduced VAT among African Union Member countries with exception of Angola which introduced it after three years in 2008 (Simon et al, 2013; Abate 2011).

According to the VAT proclamation no. 285/2002 of Ethiopia, the country adopted VAT to overwhelmed the inconvenience of the sales tax. The intention for adoption VAT therefore was as follows. First, VAT assent to the collection of further taxes compared to sales taxes is high. VAT, permits the collection of revenue at each stage of production, while the latter cannot do this. Secondly, VAT restrains the attempt of tax evasion. Afterward, VAT is a consumption tax. Thus it enhances consumption and investment. Finally, VAT advances the link between GDP and government revenue and hence increase the growth of Ethiopia

In Ethiopia, the growth rate VAT revenue is $66.27 \%$ between the study period of $2003-2012$ and the average ratio of VAT to GDP was $2.95 \%$ during the same period. His scholarly work has confirmed that value-added tax has a positive significant impact on the economic growth of Ethiopia. In his study on value-added tax as a tool for national development in Ethiopia, he also found that VAT is an important resource in countrywide enhancement (Jalata,2014).

However, adherents of societies and various stakeholders have been raising their reservation in the sense that VAT is taking a peal on the prices of their products. From the angle of economics, it is likely to anticipate that the price of goods subject to VAT rises. However, beyond this natural expectation businesses are taking the advantage of the existence of VAT to increase the aggregate price of goods and services haphazardly deprived of any economic reason. This was reinforced by Aruwa et al.(2008) when he argued that the resulting price upsurge 
causes inflation. Mclure (1989) also supported this idea by generating the idea that before considering the adoption of VAT, the macroeconomic impact of it, especially on inflation, output, income, and consumption should be the concern of policymakers.

There are few empirical works on the macroeconomic impact of VAT in developing countries especially on the price level in general and in the Ethiopian Context in particular. Ajakaiye (1999), who conducted the most comprehensive study about the influence of VAT on key sectors' macroeconomic aggregates, followed a Computable General Equilibrium (CGE) model for the Nigerian economy. While studying the impact of VAT on price stability, Marius and Alwell (2013), exhausting partial equilibrium analysis, concluded that VAT has a strong positive significant effect on prices for the study period of 1994 - 2010 prompting the finding of Ajakaiye (1999), that VAT is more deleterious when viewed as a cost. On the other hand, Olatunji (2013) Studied VAT and inflation from 1990 to 2003 for the economy of Nigeria and found that VAT has not exaggerated the intensification or diminution in inflation rate in Nigeria for the period under examination.

The involvement of these scholars in the real context of Ethiopia, with exception of Jalata (2014) and Alemu (2011) and Yesegat (2008), who engrossed in VAT impact on GDP, is overlooked as there is no all-embracing empirical work steered on the casual relationship between VAT and inflation in Ethiopia. The study of these authors focused on the contribution of VAT to economic growth. However, when the governments raise revenue using several ways such as VAT, the aggregate price level (inflation) in the economy may be distorted as inflation is a multifaceted phenomenon in the economy. Especially, in emerging countries like Ethiopia, such studies are very important in pinpointing the sources of inflation to combat the adverse effect of the revenues of government on the inflation. Consequently, this study emphases an empirical inquiry of the association between VAT and aggregate price level as well as whether VAT causes inflation or not in Ethiopia for the quarters of 2004 to 2014.

Furthermore, though there is a general perception that VAT is a significant source of revenue for economic growth and national development in Ethiopia, detractors of the policy according to Marius and Alwell (2013) contend that VAT can result in a skyward burden on aggregate prices and the negative consequences of it outweigh the gains derived from the revenue. The cause for this is associated especially with problematic management of tax administration since many of the developing countries absent administrative capabilities in the areas of the tax system. Consequently, this study is accompanied to examine the soundness of the claims of the different parts of society. The study will have also its major attentiveness in investigating the causal relationship between Value added tax on inflation using Granger causality analysis as there is no comprehensive work done on the casual relationship between VAT and inflation in the context of Ethiopia since its introduction. The study aimed mainly at examining the Causal relationship between Value added tax (VAT) and inflation in Ethiopia with the aid of Granger causality analysis.

\section{Review of Literatures}

Inflation, which most of the peoples consider as bad to the economy, mainly defined as the persistent escalation in the overall price of goods and services. The annual percentage upsurge helps to measure it. It also determines the purchasing supremacy of the currency of the countries. The incessant or sustained shrinkage of the value of money can be also taken as another meaning of inflation. The get higher inflation to dwindle the value of money and go down of inflation results in an increase in the value of money (Ashwani, 2014).

In different times numerous theories of inflation were developed. This section takes some time to discuss some of the inflation-related theories. These are the monetarist theory of inflation, structuralist theories of inflation, and Keynesian theories of inflation.

\section{a. Monetarists Theories of Inflation}

This theory was developed by one of the well-known economists Milton Freidman. In his work Friedman (1968), as cited by Gyebi and Boafo (2013), advocated that inflation is a monetary phenomenon. In the words of Freidman, it was explained as "always and everywhere inflation is monetary phenomenon is created when too few goods are purchased by too much money. This theory has its base on the quantity theory of money. The quantity theory of money associates the level of price with money supply in the economy. Thus for monetarists an increase in the level of money supply increase the level of price. The monetarist approach assumes three things in their theory. The first that the velocity of money is constant given the nominal level of money supplied and price level. They also assume that the volume of total real outcome is constant in the long run. The monetarists' final assumption is that money supply can be controlled independently of demand for money in the economy

\section{b. Structuralists Theory of Inflation}

Unlike, monetarists this theory of money advocates the structure of the economy as the main reason for the consistent rise of the price level. Thus, this theory argues that structural rigidities in the economy and sociopolitical factors in the economy are the main responsible factors for the rise in the price level in the economy. It also views inflation from the aspect of the structure of the economy. Thus, them solving economic bottlenecks such as shortage of agricultural products and exchange rates in the economy can help to attain a low level of inflation in the economy (Gyebi and Boafo 2013). 


\section{c. Keynesian's Theory of Inflation}

The Keynesians theory of inflation asserts that the force of demand and supply in the economy is responsible for the rise in the general price level. For these approach trade unions (organized institutions can force the price to rise when they ask for a wage increase. Therefore, any rise in excess production causes inflation in the absence of excess demand. This time increased wages transferred to increased prices and causes increased prices and also inflation. Generally, this approach to inflation supports the cost-push inflation theory. The other aspect of Keynesian's inflation theory is that it makes the level of employment in the economy the main cause of inflation in the short run. When the expenditure in the economy is greater than the excess demand for real output in the economy, the general price rises and causes inflation (Gyebi and Boafo 2013).

\section{d. Rational Expectation Theory of Inflation}

This theory was developed during the macroeconomic revolution of the 1970s. The idea was dominated by rational expectations including the golden idea of Lucas (1972). This theory assumes that economic agents use both past and current information to make decisions rationally. It not only considers backward-looking information but also forward-looking adoptive price expectation in the sense that agents expect a rise in price if authorities announce a monetary stimulus. This theory has also a unique behavior i.e. when the government announces to reduce inflation; the agents know that the announcement itself is not enough but effective implementation of the announcements (Omoke and Oruta, 2010).

\section{e. New Neoclassical Inflation Synthesis}

The new neoclassical synthesis of inflation considers that the main aspects responsible for inflation are the demand and monetary factors. For this theory synthesis view expectation is the main responsible factor for inflation. According to them, monetary policy can manage expectation, but the synthesis of expectation is very difficult to manage, and this why it is the main determinant of inflation under this theory. In this theory, price levels in an economy are considered as an endogenous variable and enable Keynesians as well as the real business cycle to operate differently (Tripathi et al. 2011).

\section{f. Neo political Macroeconomics of Inflation Theory}

The nonpolitical theory of inflation mainly focuses on factors that affect the economy. Moreover, it focuses on the situations of institutions, culture, and political process. This theory even provides an empirical relationship between election, policy maker's performance, and Political Process in an economy. It also provides an empirical relationship between election, policy maker's performance, and political instability. This theory also makes attention to policy credibility, inflation process, and reputation. According to this theory, the budget deficit is the main cause of inflation especially when government expends more to lob peoples during the election (Omoke and Oruta, 2010).

\section{g. The Fiscal Theory of Price Level}

The fiscal theory of inflation postulates that the monetary policy is not the only way to control inflation. It shows the importance of fiscal authorities in inflation control. This theory of inflation assumes that the fiscal deficit is exogenously determined. The well-known advocator of this theory is Surgent and Wallace (1981) who introduced the unpleasant monetarist hypothesis. Moreover, this model creates a link between fiscal and monetary policy using the issue of the inter-temporal budget constraint. This theory makes the fiscal deficit the most responsible factor to affect the price level. Accordingly, causality runs from fiscal deficit to inflation and then after from growth of money supply to the price level. Thus, according to this theory, it is a disturbance in the financial sector that affects the money supply in the economy implying neutrality of money supply in the environment of nonRicardian theory. This shows the idea of monetarists about inflation is contested by fiscalists. The fiscal theory of inflation argues that inflation is also influenced by the fiscal authorities. According to this theory, government budget deficit constraint is helped as the condition of equilibrium (Lozano, 2008, Daniel, 2004).

The fiscal theory of price level has two versions. One is the strong fashion of it while the other is the weak aspect. The former supports that even if the money supply growth remains constant, fiscal policy has the capacity of autonomously influencing price level, and the latter posits that monetarists have still power. And, the growth of the money supply s dictated by the monetary authorities. Moreover, the weak form of fiscal theory assumes that fiscal policy does not indirectly affect the price level showing their independence from the monetary policy responses.

Generally, this theory implies that the growth of the money supply plays a passive role in the long run as the main cause of inflation is through deficit (Daniel, 2004, Carlstorm and Fuerst, 1999).

\section{Methods and Materials}

\subsection{Sources of Data}

The study employed quarterly time series data for the period of 2004Q1-2014Q4. The data are sourced from the National Bank of Ethiopia (NBE) and Central Statistical Authorities (CSA). This shows that the data used in the study is reliable as it is sourced from recognized national institutions. 


\subsection{Variables of the Study}

The described variables should be clearly defined in any scientific investigation. Thus, this section deals with the definition of variables. This study has six variables. The dependent variable is the consumer price index while the left five are explanatory variables. The definitions of the variables in the view of this study are given as follows.

1. A Consumer Price Index (CPI): this index is used as a proxy of inflation in this study. It is a measure of changes in the price level of general goods and services purchased by households.

2. Value Added Tax (VAT): in Ethiopia or elsewhere, VAT is defined as a tax on an exchange that is levied on the value-added that results from each stage of the exchange.

3. Fiscal Deficit (FDFCT): it is the accumulation of deficit at different times. In other words, it can be defined as a summation of the budget of past years.

4. Real Effective Exchange Rate (REEER): it is an indicator obtained by deflating the nominal effective exchange rate (a measure of the value of a currency against a weighted average of several foreign currencies) by a suitable effective deflator.

5. Broad Money (Money Supply) (BRDM): it is a variable that explains the total amount of monetary asset available in an economy at a specific amount of time, say quarter in this study case.

6. Import (IMPT): another variable used in this study is imported (IMPT) and it can be defined as a good or service brought from an external border especially across the national border.

\subsection{The Granger Causality Model Specification}

When conducting empirical research we may be interested in determining the direction of causality between or among given variables. If the interest of empirical investigators is to the direction of causality, the application of Granger causality is among the most popular and commonly applied in econometric investigations.

According to Ulke and Ergun (2011), the concept of Granger causality was first developed by Clive William John Granger (1934-2009) who won the noble price in 2003 for his method of analyzing the time series with the common trend in 1969.

The simple definition of causality can be explained using two variables $\mathrm{X}$ and $\mathrm{Y}$, that is, if the partial value of $\mathrm{X}$ can predict the present value of $\mathrm{Y}$, then there is a causality running from $\mathrm{X}$ to $\mathrm{Y}$. Causality can be tested with the objectives such as finding the direction of causality, finding how many times change in one variable affect the other and also to overcome structural changes. Toward the achievement of the objective of this study, the Pairwise Granger causality test is conducted to capture the direction of causality between VAT and price level in Ethiopia.

Sometimes, there is a possibility in which the relationship we know in the theory may not work due to the reasons we cannot identify. Thus, to make sure whether the past changes are responsible for the current observation, establishing the idea of causality test has much importance. Ajisafe (2006) noted that causation runs from X to $\mathrm{Y}$ if the past and present values of $\mathrm{X}$ are different from zero. The same is true when causation runs from $\mathrm{Y}$ to $\mathrm{X}$, and however, if the results are significantly different from zero causation runs from both sides. This study used the Granger causality test to investigate the causation between VAT and price level in Ethiopia.

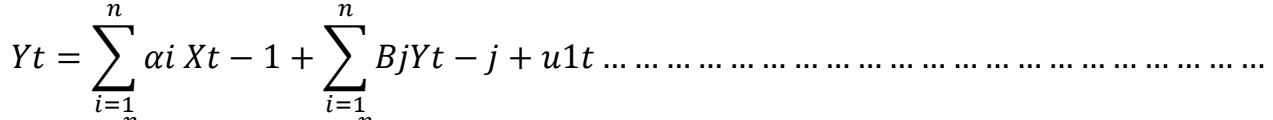

$$
\begin{aligned}
& X t=\sum_{i=1}^{n} \gamma i X t-i+\sum_{i=0}^{n} \delta j Y t-j+u 2 t
\end{aligned}
$$

Equation (3.31) shows that the present value dependent variable is associated with the past value of the explanatory variable where $\mathrm{X}$ is the independent variable and $\mathrm{Y}$ is the dependent variable. The null hypothesis for the equation is that the Variable $\mathrm{X}$ (explanatory) does not Granger causes the dependent variable( $\mathrm{Y}$ ) while the alternative hypothesis is that $\mathrm{X}$ granger causes $\mathrm{Y}$. The rejection of the null hypothesis thus will depict that there is causality between $\mathrm{X}$ and $\mathrm{Y}$. To reject or accept the null hypothesis however the result of the calculated $\mathrm{F}$ value result should be compared with the value of F-statistics critical value computed as follows.

$$
F=\frac{\mathrm{RSS}_{\mathrm{R}}-\mathrm{RSS}_{\mathrm{UR} / \mathrm{m}}}{\mathrm{RSS}_{\mathrm{UR}} /(\mathrm{n}-\mathrm{K})}
$$

Where $\mathrm{F}$ is the result of F statistics, RSSR is regression obtained from running variables including lagged $\mathrm{Y}$ values in the form of Residual Some of Squared excluding lagged values of X; RSSUR is the unrestricted residual sum of square obtained from running regression excluding the lagged variables of Y. m represent the number of restrictions while $\mathrm{K}$ is the number of parameters and Finally, shows the number of observation.

When testing the Granger Causality, the following possibilities may be obtained. As proposed by Granger they are four in number. The first is unidirectional causality from saying for example $X$ to $Y$, which happens when the estimated lagged coefficient of $\mathrm{X}$ variables is not statistically different from zero and lagged coefficients of $\mathrm{Y}$ 
variables are statistically not different from zero. The second possibility during the Granger causality test is unidirectional causality from $\mathrm{Y}$ to $\mathrm{X}$ in our particular example.

This type of unidirectional causality happens when the lagged coefficient of $\mathrm{X}$ is statically different from zero and that $\mathrm{Y}$ is not. Thirdly, one may come across the situation where the lagged coefficient of both variables $\mathrm{X}$ and $\mathrm{Y}$, for our case, is statistically different from zero. This type of Causality is Called bidirectional causality. In this case, causality runs from $\mathrm{X}$ to $\mathrm{Y}$ as well as from $\mathrm{Y}$ to $\mathrm{X}$. The final Possibility may be a situation where the coefficient of both Variables: $\mathrm{X}$ and Yin in our case, not statistically different from zero. That is when the coefficient of both $\mathrm{X}$ and $\mathrm{Y}$ in our hypothetical example is independent of each other. This type of Granger causality possibility is called independence causality. Using the specified Granger causality model, it is now scientifically and procedurally safe to proceed to discussions of the results of the study.

Data analysis was accompanied by exhausting the e-view 7.1 econometrics software package. The econometric software is favored due to its expediency and better performance in the analysis of time-series data (Vogelvang, 2005).

\section{Results and Discussions}

\subsection{The Unit Root Test of Variables}

\section{a. ADF Unit Root at the Level and First Difference}

Unit root test is among the vital conditions of econometric studies since stationary data are required in the process of analysis. Formally, the Unit root test in this study is conducted using:

Equation (a) consists of the ADF model without the intercept and constant while equation (b) is the model with constant. Equation (c) consists of both trend and intercept.

$\mathrm{Y}_{\mathrm{t}}=\delta \alpha y_{t-1}+\mathrm{a}_{\mathrm{i}}+\mu_{\mathrm{t}}$

$$
\begin{gathered}
\Delta Y_{t}=\alpha_{o}+\alpha Y_{t}-1+\sum_{i-1}^{n} \emptyset i \Delta \mathrm{Y}_{t-i}+\omega_{\mathrm{t}} \ldots . . \\
\Delta Y_{t}=a_{o}+\alpha_{1} Y_{t-1}+\alpha_{2 t} \sum_{i=1}^{n} \emptyset \mathrm{i} \Delta \mathrm{Y}_{\mathrm{t}-1}+\omega
\end{gathered}
$$

$\omega t=$ represents stochastic variables while $Y t=$ represents time series variables in the study.

The Augmented Dickey-Fuller unit root test results at the level and first differencing are shown in table 4.1 and table 4.2.

\begin{tabular}{|c|c|c|c|c|c|c|}
\hline \multirow[t]{2}{*}{ Variable } & \multicolumn{4}{|c|}{ Augmented Dickey-Fuller (ADF)Test Equation (Level) } & \multirow[b]{2}{*}{ None } & \multirow[b]{2}{*}{$\begin{array}{l}5 \% \text { Critical } \\
\text { Value }\end{array}$} \\
\hline & Constant & $\begin{array}{l}5 \% \text { Critical } \\
\text { Value }\end{array}$ & $\begin{array}{l}\text { Constant and } \\
\text { Trend }\end{array}$ & $\begin{array}{l}5 \% \text { Critical } \\
\text { Value }\end{array}$ & & \\
\hline LOGCPI & $-1.170321 * *$ & $\begin{array}{l}-3.536601 \\
(0.6786)\end{array}$ & $-1.916036 * *$ & $\begin{array}{l}-3.536601 \\
(0.6261)\end{array}$ & $-0.296860 * *$ & $\begin{array}{l}-1.948686 \\
(0.5730)\end{array}$ \\
\hline LOGFDFCT & $-2.029056^{* *}$ & $\begin{array}{l}-2.931404 \\
(0.2738)\end{array}$ & $-2.031483 * *$ & $\begin{array}{l}-3.518090 \\
(0.5680)\end{array}$ & $-1.377332 * *$ & -1.948686 \\
\hline LOGREER & $-2.126964 * *$ & $\begin{array}{l}-2.931404 \\
(0.2355)\end{array}$ & $-2.157372 * *$ & $\begin{array}{r}-3.518090 \\
(0.5003) \\
\end{array}$ & $-1.917213 * *$ & $\begin{array}{l}-1.948686 \\
(0.0535)\end{array}$ \\
\hline LOGVAT & $-1.012474 * *$ & $\begin{array}{l}-2.931404 \\
(0.7405)\end{array}$ & $-2.032045 * *$ & $\begin{array}{c}-3.518090 \\
(0.5677)\end{array}$ & $-0.036525 * *$ & $\begin{array}{l}-1.948686 \\
(0.6650)\end{array}$ \\
\hline LOGBRDM & $-0.521722 * *$ & $\begin{array}{l}-2.931404 \\
(0.8769)\end{array}$ & $-1.437692 * *$ & $\begin{array}{l}-3.518090 \\
(0.8352)\end{array}$ & $-0.443852 * *$ & $\begin{array}{l}-1.948686 \\
(0.5186)\end{array}$ \\
\hline LOGIMPT & $-1.567914^{* *}$ & $\begin{array}{l}-2.931404 \\
(0.4900)\end{array}$ & $-1.366166^{* *}$ & $\begin{array}{l}-3.518090 \\
(0.8596)\end{array}$ & $-0.438521 * *$ & $\begin{array}{l}-1.948686 \\
(0.5186)\end{array}$ \\
\hline
\end{tabular}

Table 4.1: Results of ADF unit root tests at the level

Source: Own computation from e-view 7.1

Note: ** Shows non Rejection of the presence of unit root (the null Hypotheses) at 1\%, 5\%, and 10\% level of significance. Numbers in () is the Probability values (Mackinnon (1996) one-sided P-values. The critical values for Constant are -3.592462 and -2.603944 for $1 \%$ and $10 \%$ level of significance respectively. The critical Values for Constant and trend are -4.186481 , and-3.189732 for $1 \%$ and $10 \%$ respectively. And the critical values for none are -2.619851 and -1.612036 at $1 \%$ and $10 \%$ level of significances. 
Table 4.2: Result of ADF Unit root Test Result at the First Difference

\begin{tabular}{|c|c|c|c|c|c|c|c|}
\hline \multirow[t]{2}{*}{ Variable } & \multicolumn{6}{|c|}{ Augmented Dickey-Fuller (ADF) Test Equation (First Difference) } & \multirow[t]{2}{*}{$\mathrm{I}(\mathrm{d})$} \\
\hline & Constant & $\begin{array}{l}5 \% \text { Critical } \\
\text { Value }\end{array}$ & $\begin{array}{l}\text { Constant and } \\
\text { Trend }\end{array}$ & $\begin{array}{l}5 \% \text { Critical } \\
\text { Value }\end{array}$ & None & $\begin{array}{ll}5 \% & \text { Critical } \\
\text { Value } & \\
\end{array}$ & \\
\hline LOGCPI & $-6.423763 *$ & $\begin{array}{l}-2.933158 \\
(0.0000)\end{array}$ & $-6.345536^{*}$ & $\begin{array}{l}-3.520787 \\
(0.0000) \\
\end{array}$ & $-6.497052 *$ & $\begin{array}{l}-1.948886 \\
(0.0000)\end{array}$ & $\mathrm{I}(1)$ \\
\hline LOGFDFCT & $-6.316745^{*}$ & $\begin{array}{l}-2.933158 \\
(0.0000)\end{array}$ & $-6.300484 *$ & $\begin{array}{l}-3.520787 \\
(0.0000)\end{array}$ & $-6.367730^{*}$ & $\begin{array}{l}-1.948886 \\
(0.0000)\end{array}$ & $\mathrm{I}(1)$ \\
\hline LOGREER & $-4.469424 *$ & $\begin{array}{l}-2.941145 \\
(0.0000)\end{array}$ & $-4.448414 *$ & $\begin{array}{l}-3.448414 \\
(0.0000)\end{array}$ & $-4.534097 *$ & $\begin{array}{l}-4.534097 \\
(0.0000)\end{array}$ & $\mathrm{I}(1)$ \\
\hline LOGVAT & $-6.458449 *$ & $\begin{array}{l}-2.933158 \\
(0.0000)\end{array}$ & $-6.499152 *$ & $\begin{array}{l}-3.520787 \\
(0.0000)\end{array}$ & $-6.403069 *$ & $\begin{array}{l}-1.948886 \\
(0.0000)\end{array}$ & $\mathrm{I}(1)$ \\
\hline LOGBRDM & $-5.881076^{*}$ & $\begin{array}{l}-2.933158 \\
(0.0000)\end{array}$ & $-5.832347 *$ & $\begin{array}{l}-3.520787 \\
(0.0001)\end{array}$ & $-5.539975^{*}$ & $\begin{array}{l}-1.948886 \\
(0.0000)\end{array}$ & $\mathrm{I}(1)$ \\
\hline LOGIMPT & $-6.360523 *$ & $\begin{array}{l}-2.933158 \\
(0.0000)\end{array}$ & $-6.797921 *$ & $\begin{array}{l}-3.520787 \\
(0.0000)\end{array}$ & $-6.439533 *$ & $\begin{array}{l}-1.948886 \\
(0.0000)\end{array}$ & $\mathrm{I}(1)$ \\
\hline
\end{tabular}

Source: Own calculation from e-view 7.1

Note: * shows the rejection of null hypothesis (Variables are stationary) at first differencing at 1\%, 5\%, 10\% level of significance. Numbers in () is the Probability values (Mackinnon (1996) one-sided P-values The critical values for Constant are -3.596616 and - 2.604867 for 1\% and $10 \%$ level of significance respectively. The critical Values for Constant and trend are -4.192337 , and-3.191277 for $1 \%$ and $10 \%$ respectively. And the critical values for none are -2.621185 and -1.611932 at $1 \%$ and $10 \%$ level of significances.

In the Augmented Dickey-fuller Unit root test, the null hypothesis is that the series has the unit root against the alternative hypothesis of no unit root. Cleary speaking, under the unit root test of Augmented Dickey fuller the variables are not stationary at their level but stationary at their first differencing.

\section{b. Phillips-Perron(PP) unit root ADF Unit Root at the level and First Difference}

In this study, the ADF result is crosschecked using the Phillips-Perron unit root test to capture the criticisms of the ADF test. The Philips- Perron unit root test, which gives robust estimates especially in the presence of structural break (Maddala, 1992) is given as:

$$
Y t=\mu o+\mu 1\left(\mathrm{t}-\frac{\mathrm{T}}{2}\right)+\alpha o Y \mathrm{t}-1+\sum_{\mathrm{i}=1}^{\mathrm{m}} \omega \Delta \mathrm{Yt}-1+\mathrm{ut}
$$

Where, $\mathrm{m}$ is the lag length of the PP unit root test and $\mathrm{T}$ is the number of observations used in the PP unit root test. In the Phillips Perron, Unit root tests the lag length to be used the test is determined based on Newey and West bandwidth as it was suggested by Newey and West (1994). The results of the PP unit root test are depicted below at both their levels and in their first differencing. Table 4.3 below shows the result of the PP test at the level of the series and the next table 4.4 shows the PP test for unit root the first differencing of the variables. 
Table 4.3: Results of PP Unit Root tests of Variables at level

\begin{tabular}{|c|c|c|c|c|c|c|}
\hline Variable & \multicolumn{6}{|c|}{ Phillips-Perron (PP) unit Root Test Equation (Level) } \\
\hline & Constant & $\begin{array}{l}5 \% \text { Critical } \\
\text { Value }\end{array}$ & $\begin{array}{l}\text { Constant and } \\
\text { Trend }\end{array}$ & $\begin{array}{l}5 \% \text { Critical } \\
\text { Value }\end{array}$ & None & $\begin{array}{l}5 \% \text { Critical } \\
\text { Value }\end{array}$ \\
\hline LOGCPI & $-1.171079 *$ & $\begin{array}{l}-2.931404 \\
(0.6783)\end{array}$ & $-1.699229 *$ & $\begin{array}{l}-3.518090 \\
(0.7344)\end{array}$ & $-0.296436^{*}$ & $\begin{array}{l}-1.948686 \\
(0.5730)\end{array}$ \\
\hline LOGFDFCT & $-2.065696^{*}$ & $\begin{array}{l}-2.931404 \\
(0.2590)\end{array}$ & $-2.167526 *$ & $\begin{array}{l}-3.518090 \\
(0.8645)\end{array}$ & $-1.410326^{*}$ & $\begin{array}{l}-1.948686 \\
(0.1453)\end{array}$ \\
\hline LOGREER & $-2.311108^{*}$ & $\begin{array}{c}-2.931404 \\
(0.1732)\end{array}$ & $-2.334652 *$ & $\begin{array}{l}-3.518090 \\
(0.4070)\end{array}$ & $-2.064016^{*}$ & $\begin{array}{c}-1.948686 \\
(0.0387)\end{array}$ \\
\hline LOGVAT & $-1.012474 *$ & $\begin{array}{l}-2.931404 \\
(0.7405)\end{array}$ & $-2.142070 *$ & $\begin{array}{l}-3.518090 \\
(0.5085)\end{array}$ & $-0.036525^{*}$ & $\begin{array}{l}-1.948686 \\
(0.6650)\end{array}$ \\
\hline LOGBRDM & $-0.579594 *$ & $\begin{array}{c}-2.931404 \\
(0.8645)\end{array}$ & $-1.619104 *$ & $\begin{array}{l}-3.518090 \\
(0.7688)\end{array}$ & $-1.794211 *$ & $\begin{array}{c}-1.948686 \\
(0.9809)\end{array}$ \\
\hline LOGIMPT & $-1.642371 *$ & $\begin{array}{c}-2.931404 \\
(0.4527)\end{array}$ & $-1.310009 *$ & $\begin{array}{c}-3.518090 \\
(0.8721)\end{array}$ & $-0.438359 *$ & $\begin{array}{c}-1.948686 \\
(0.5187)\end{array}$ \\
\hline
\end{tabular}

Source: Own calculation from e-view 7.1

Note: * shows the presence of unit root (non-rejection of the null hypothesis) under the PP test at a level at 1\%,5\%, and 10\% level of significance Numbers in () is the Probability values (Mackinnon (1996) one-sided P-values. The critical values for Constant are -3.592462 and -2.603944 for $1 \%$ and $10 \%$ level of significance respectively. The critical Values for Constant and trend are -4.186481, and-3.189732 for $1 \%$ and $10 \%$ respectively. And the critical values for none are -2.619851 and -1.612036 at $1 \%$ and $10 \%$ level of significances.

Table: 4.4: The Result of the Phillips- Perron Unit Root Test at first Difference

\begin{tabular}{|c|c|c|c|c|c|c|c|}
\hline Variable & \multicolumn{6}{|c|}{ Phillips-Perron (PP) unit Root Test Equation ( First Differencing ) } & $\mathrm{I}(\mathrm{d})$ \\
\hline & Constant & $\begin{array}{l}5 \% \\
\text { Critical } \\
\text { Value }\end{array}$ & $\begin{array}{l}\text { Constant } \\
\text { and Trend }\end{array}$ & $\begin{array}{l}5 \% \text { Critical } \\
\text { Value }\end{array}$ & None & $\begin{array}{l}5 \% \text { Critical } \\
\text { Value }\end{array}$ & \\
\hline LOGCPI & -6.423644 & $\begin{array}{c}-2.933158 \\
(0.0000)\end{array}$ & -6.345068 & $\begin{array}{r}-3.520787 \\
(0.0000)\end{array}$ & -6.497186 & $\begin{array}{r}-1.948886 \\
(0.0000)\end{array}$ & $\mathrm{I}(1)$ \\
\hline LOGFDFCT & -6.316745 & $\begin{array}{c}-2.933158 \\
(0.0000)\end{array}$ & -6.300336 & $\begin{array}{c}-3.520787 \\
(0.0000)\end{array}$ & -6.36773 & $\begin{array}{c}-1.948886 \\
(0.0000)\end{array}$ & $\mathrm{I}(1)$ \\
\hline LOGREER & $-4.469424 *$ & $\begin{array}{c}-2.933158 \\
(0.0000)\end{array}$ & $-4.448414 *$ & $\begin{array}{c}-3.520787 \\
(0.0000)\end{array}$ & $-4.534097 *$ & $\begin{array}{c}-1.948886 \\
(0.0000)\end{array}$ & $\mathrm{I}(1)$ \\
\hline LOGVAT & -6.458450 & $\begin{array}{c}-2.933158 \\
(0.0000)\end{array}$ & -6.499159 & $\begin{array}{c}-3.520787 \\
(0.0000)\end{array}$ & -6.403069 & $\begin{array}{l}-1.948886 \\
(0.0000)\end{array}$ & $\mathrm{I}(1)$ \\
\hline LOGBRDM & -5.881076 & $\begin{array}{l}-2.933158 \\
(0.0000)\end{array}$ & -5.832347 & $\begin{array}{c}-3.520787 \\
(0.0001)\end{array}$ & -5.558407 & $\begin{array}{l}-1.948886 \\
(0.0000)\end{array}$ & $\mathrm{I}(1)$ \\
\hline LOGIMPT & -6.360567 & $\begin{array}{c}-2.933158 \\
(0.0000)\end{array}$ & -7.519263 & $\begin{array}{c}-3.520787 \\
(0.0000)\end{array}$ & -6.439548 & $\begin{array}{l}-1.948886 \\
(0.000)\end{array}$ & $\mathrm{I}(1)$ \\
\hline
\end{tabular}

Source: Own calculation from e-view 7.1

Note: * shows the rejection of null hypothesis (Variables are stationary) at first differencing at 1\%, 5\%, 10\% level of significance. Numbers in () is the Probability values (Mackinnon (1996) one-sided P-values The critical values for Constant are -3.596616 and - 2.604867 for $1 \%$ and $10 \%$ level of significance respectively. The critical Values for Constant and trend are -4.192337 , and-3.191277 for $1 \%$ and $10 \%$ respectively. And the critical values for none are -2.621185 and -1.611932 at $1 \%$ and $10 \%$ level of significances.

In the Phillips -Perron unit root test the null hypothesis is the presence of unit root while the alternative hypothesis is the absence of unit roots in the corresponding series. We also fail to reject the null hypothesis of unit root at the level in the PP. Generally speaking, the conducted unit root tests reveal that variables are non-stationary at the level and have to be differenced to achieve stationary of data in the analysis. It follows that data are stationary at their first differencing. The reality of this is confirmed by both ADF and PP unit root tests. In other words, both tests checked that variables have a unit root at level but stationary at their first difference. Thus, it is now safe and sufficient to conclude that variables are stationary at their first difference and hence I (1).

\subsection{Akaike Information Criteria (AIC) of Lag Length Selection}

In this research, an AIC information criterion is used as it is the most familiar and supported by majorities of the criteria (see table 4.5 hereunder) and the VAR diagnostic test was used to choose lag order for the analysis. 
Table 4:5: AIC for Lag length selection

VAR Lag Order Selection Criteria

Endogenous variables: LOG_CPI LOG_FDFCT LOG_REER LOG_VAT LOGBRDM LOGIMPT

Exogenous variables: $\mathrm{C}$

Date: 03/31/16 Time: 13:35

Sample: 2004Q1 2014Q4

Included observations: 41

\begin{tabular}{|c|c|c|c|c|c|c|}
\hline \hline Lag & Log L & LR & FPE & AIC & SC & HQ \\
\hline \hline 0 & 134.7432 & NA & $7.55 \mathrm{e}-11$ & -6.280156 & -6.029390 & -6.188841 \\
1 & 298.0282 & 270.8141 & $1.55 \mathrm{e}-13$ & -12.48918 & $-10.73381^{*}$ & -11.84997 \\
& & & & & - \\
2 & 346.9856 & $66.86865^{*}$ & $9.24 \mathrm{e}-14^{*}$ & $-13.12125^{*}$ & -9.861281 & $11.93415^{*}$ \\
3 & 380.4110 & 35.87123 & $1.45 \mathrm{e}-13$ & -12.99566 & -8.231095 & -11.26067 \\
\hline \hline
\end{tabular}

* indicates lag order selected by the criterion

LR: sequential modified LR test statistic (each test at 5\% level)

FPE: Final prediction error

AIC: Akaike information criterion

SC: Schwarz information criterion

HQ: Hanna-Quinn information criterion

Source: Own calculation from e-view 7.1

As it is depicted in table 4.5, it is observed that the lag order suggested by the Akaike information criterion is 2, and it is supported by the majority of other selection criteria such as Hannan-Quinn information criterion (HQ), Final prediction error (FPE), and sequentially modified LR test statistic (LR) while only Schwarz information criterion selected lag 1 which is out of majority's view. Therefore, lag 2 is accepted for the analysis indicating proceeding to the Granger causality test is now safe.

\subsection{Granger Causality Analysis Between VAT and Inflation}

Granger causality is applied due to its powerfulness and its simplicity to apply. Table 4.6 below shows the pairwise granger causality between inflation and value-added tax intending to know the direction of Granger causality. From the granger causality test as shown in table 4.6 below the null hypothesis which says real effective exchange rate does not granger cause inflation cannot be rejected since it appeared with the probability of more than five percent. At the same time, the null hypothesis saying inflation does not granger causes real effective exchange rate also cannot be rejected as the probability value $18.15 \%$ is greater than the $5 \%$ level of significance.

Given the F-statistics of 1.72378 with the probability of 0.1924 ; the Pairwise Granger causality test in 42 observations presented no causal relationship between exchange rate and level of inflation in Ethiopia. In this case, there is no Granger-causality in any direction between the real effective exchange rate and inflation. This result corroborates the findings of Oliver and Michael (2014) as they found a positive relationship but no causality between the variables. The justification here may be due to the depreciation in the real effective exchange rate of ETB that increases inflationary Pressure in Ethiopia.

The model was estimated with the two lag included 42 observations following the suggestion of lag selection criterion. Granger-causality results from table 4.11 show that the null hypothesis which says that fiscal deficit (D FDFCT) does not Granger causes inflation is rejected since the result is significant with a probability less than 0.05 which is $5 \%$. This implies that fiscal deficit could cause inflation in Ethiopia as it did during this study period. Therefore, the causal relationship found between inflation (DLOGCPI) and Fiscal deficit (DLOGFDFCT) is a unidirectional causality ruining from fiscal deficit to inflation. The result of this study is similar to the finding of Ulke and Ergun (2011), who also found unidirectional and non-feedback.

Table 4.6 also reports the results of the causality analysis of inflation (DLOGCPI) and import (DIMPT) in Ethiopia. The result of the table indicates that since the F-statistic value of import is significantly big i.e. 11.2343, therefore import does Granger causes inflation as it is also significant with the probability of 0.0002 . In other words, the null hypothesis that says import does not cause inflation can easily be rejected due to the significance of probability attached to it. However, one cannot reject the null hypothesis that says inflation does not cause import because the $\mathrm{F}$ value is very low with 0.63196 and the probability value is 0.5372 significantly greater than 5 Percent. This simply shows that inflation does not Granger causes import in Ethiopia from the first quarter of 
2004 to the last quarter of 2014. The general conclusion is that there is unidirectional causation running from import to inflation. The finding of this study is similar to what Ulke and Ergun (2011) obtained in their work as they found one-way Granger-causality running from import to inflation for the Turkish economy.

The pairwise granger causality test presented in table 4.6 reveals that broad money (M2) causes inflation in Ethiopia. The null hypothesis that says broad money does not cause inflation cannot be rejected at a $5 \%$ percent level of significance with the probability of 0.0021 and high F-statistics of 7.32657. Besides, the null hypothesis that says inflation does not cause broad money cannot also be rejected with the given probability of 0.0074 and Fstatistics of 0.575132 . Thus, in Ethiopia, there is bidirectional causality between broad money and inflation. This result coincides with the ideas of monetarists' view of inflation and money supply. This finding is also similar to the finding of Denbel et al (2016), who studied the relationship between inflation, money supply, and economic growth from 1970/71 -2010/11 and observed bidirectional causality between money supply and inflation for the study period.

Table 4.6: Pairwise Granger Causality Test Results

\section{Pairwise Granger Causality Tests}

Date: $04 / 24 / 16$ Time: 10:10

Sample: 2004Q1 2014Q4

Lags: 2

\begin{tabular}{|c|c|c|c|}
\hline Null Hypothesis: & Obs & F-Statistic & Prob. \\
\hline LOG_FDFCT does not Granger Cause LOG_CPI & 42 & 2.82561 & 0.0021 \\
\hline $\mathrm{LOG}_{-}^{-} \mathrm{CPI}$ does not Granger Cause LOG_FDFCT & & 0.25646 & 0.7751 \\
\hline LOG_REER does not Granger Cause LOG_CPI & 42 & 1.72378 & 0.1924 \\
\hline LOG_CPI does not Granger Cause LOG_REER & & 1.78787 & 0.1815 \\
\hline LOG VAT does not Granger Cause LOG CPI & 42 & 7.17168 & 0.0023 \\
\hline LOG_CPI does not Granger Cause LOG_VAT & & 1.43178 & 0.2518 \\
\hline LOGBRDM does not Granger Cause LOG_CPI & 42 & 5.75132 & 0.0074 \\
\hline LOG_CPI does not Granger Cause LOGBRDM & & 7.32657 & 0.0021 \\
\hline LOGIMPT does not Granger Cause LOG_CPI & 42 & 7.32657 & 0.0021 \\
\hline LOG_CPI does not Granger Cause LOGIMPT & & 0.69099 & 0.5074 \\
\hline LOG_REER does not Granger Cause LOG_FDFCT & 42 & 1.82347 & 0.1757 \\
\hline LOG_FDFCT does not Granger Cause LOG__REER & & 1.05693 & 0.3578 \\
\hline LOG_VAT does not Granger Cause LOG_FDFCT & 42 & 0.32619 & 0.7237 \\
\hline LOG_FDFCT does not Granger Cause LOG_VAT & & 0.03980 & 0.9610 \\
\hline LOGBRDM does not Granger Cause LOG_FDFCT & 42 & 0.77634 & 0.4674 \\
\hline LOG_FDFCT does not Granger Cause LOGBRDM & & 0.18719 & 0.8301 \\
\hline LOGIMPT does not Granger Cause LOG_FDFCT & 42 & 0.21291 & 0.8092 \\
\hline LOG_FDFCT does not Granger Cause LŌGIMPT & & 2.92532 & 0.0661 \\
\hline LOG_VAT does not Granger Cause LOG_REER & 42 & 5.73738 & 0.0068 \\
\hline LOG_REER does not Granger Cause LOG_$_{-}$VAT & & 0.01733 & 0.9828 \\
\hline LOGBRDM does not Granger Cause LOG_REER & 42 & 0.88267 & 0.4222 \\
\hline LOG_REER does not Granger Cause LOGBRDM & & 2.46304 & 0.0990 \\
\hline LOGIMPT does not Granger Cause LOG_REER & 42 & 1.56662 & 0.2223 \\
\hline LOG_REER does not Granger Cause LOG̈IMPT & & 0.28980 & 0.7501 \\
\hline LOGBRDM does not Granger Cause LOG_VAT & 42 & 2.46622 & 0.0988 \\
\hline LOG_VAT does not Granger Cause LOGBRDM & & 6.75006 & 0.0032 \\
\hline "LOGIMPT does not Granger Cause LOG_VAT & 42 & 0.56161 & 0.5751 \\
\hline LOG_VAT does not Granger Cause LOGIMPT & & 1.18190 & 0.3180 \\
\hline LOGIMPT does not Granger Cause LOGBRDM & 42 & 7.66016 & 0.0016 \\
\hline LOGBRDM does not Granger Cause LOGIMPT & & 0.04398 & 0.9570 \\
\hline
\end{tabular}

Source: Own computation from e-view 7.1

\subsection{Long and Short Run Causality Between VAT and Inflation}

As it is possible to see from table 4.7 below, the error correction term in the equation of LOGCPI is negative and also significant at a $5 \%$ percent level of significance. This automatically tells the presence of a long-run 
relationship running from value-added tax (VAT) to inflation. Generally speaking, it also implies the presence of a long-run relationship running from explanatory variables of the study (FDFCT, REER, VAT, BRDM, and IMPT) to the dependent variable of the study (LOGCPI). The result from the VECM has shown that the speed of adjustment is negative 0.4790 . This result implies that 47.9 percent of disturbances (disturbances) are corrected in the consumer price index or inflation (LOGCPI) equation is adjusted each quarter (every three months). From the observed result, the speed of adjustment i.e. disequilibrium that results from a change in one of the explanatory variables in the short run is not as fast and it is $47.9 \%$ implying that there is no full adjustment within two quarters. Regarding the variables, the sign of error correction term when VAT is dependent variable is negative and but not significant at $5 \%$ level of significance ( -1.67359 and 0.1058 , error correction term and t-probability respectively) showing only unidirectional causality running from Value added tax(VAT) to the price level in Ethiopia in long run. This result is similar to the report of the Granger causality test result reported in table 4.7 above.

When the FDFCT is a dependent variable the sign of error correction term is found to be negative and as well significant. This result reflects that there is bidirectional causality between fiscal deficit and inflation in Ethiopia from the first quarter of 2004 to the final quarter of 2014. Unlike the VECM estimates, there is unidirectional Granger causality running from LOGFDFCT to LOGCPI. The result of Table 4.7 also revealed that there is bidirectional causality between import (IMPT) and inflation in Ethiopia in the long run since the sign of error correction term is both negative and significant when the error term is positive and significant when the import is taken as a dependent variable in long run. The pair-wise Granger causality test however reported that there is a unidirectional causality running from IMPT to CPI. The result of Table 4.7 further revealed that there is an only unidirectional causality running from BRDM (Money supply) and real effective exchange rate (REER) to inflation (CPI) in the long run when BRDM and REER are taken as the dependent variable as the error correction term associated to them is negative but insignificant. The reported result by VECM is similar to the report of the Pairwise Granger causality test result reported in the previous section.

Table 4.7: Long run and short-run causality from VECM estimation result

\begin{tabular}{|c|c|c|c|c|c|c|}
\hline $\begin{array}{l}\text { Explanatory } \\
\text { Variables: }\end{array}$ & $\mathrm{D}\left(\mathrm{LOG} \_\mathrm{CPI}\right)$ & $\mathrm{D}($ LOGFDFCT) & D(LOG_REER) & D(LOG_VAT) & D(LOG_BRDM) & D(LOGIMPT) \\
\hline ECOTCPI-1 & $\begin{array}{c}-0.479097 \\
(0.0102) \\
{[-2.76303]}\end{array}$ & $\begin{array}{c}-0.000590 \\
(0.0227) \\
{[-2.41622]}\end{array}$ & $\begin{array}{r}-6.19 \mathrm{E}-05 \\
(0.46611) \\
{[-0.73931]}\end{array}$ & $\begin{array}{c}-23.96577 \\
(0.1058) \\
{[-1.67359]}\end{array}$ & $\begin{array}{c}-0.000368 \\
(0.2640) \\
{[-1.14068]}\end{array}$ & $\begin{array}{c}-3.09 \mathrm{E}-05 \\
(0.0240) \\
{[2.39240]}\end{array}$ \\
\hline D(LOG_CPI(-1)) & $\begin{array}{r}0.494961 \\
(0.0511) \\
{[2.04125]}\end{array}$ & $\begin{array}{c}0.000106 \\
(0.7576) \\
{[0.31183]}\end{array}$ & $\begin{array}{c}-5.07 \mathrm{E}-06 \\
(0.9658) \\
{[-0.04330]}\end{array}$ & $\begin{array}{c}44.77821 \\
(0.0338) \\
{[2.23609]}\end{array}$ & $\begin{array}{c}0.000449 \\
(0.3280) \\
{[0.99619]}\end{array}$ & $\begin{array}{c}-4.61 \mathrm{E}-05 \\
(0.0166) \\
{[-2.55426]}\end{array}$ \\
\hline D(LOG_CPI(-2)) & $\begin{array}{c}0.207072 \\
(0.2822) \\
{[1.09738]}\end{array}$ & $\begin{array}{c}-2.71 \mathrm{E}-05 \\
(0.9194) \\
{[-0.10208]}\end{array}$ & $\begin{array}{c}4.75 \mathrm{E}-06 \\
(0.9588) \\
{[0.05215]}\end{array}$ & $\begin{array}{c}41.66948 \\
(0.0126) \\
{[2.67395]}\end{array}$ & $\begin{array}{c}0.000174 \\
(0.6231) \\
{[0.49721]}\end{array}$ & $\begin{array}{c}-2.83 \mathrm{E}-05 \\
(0.0542) \\
{[-2.01256]}\end{array}$ \\
\hline D(LOGFDFCT(-1)) & $\begin{array}{c}0.455126 \\
(0.1802) \\
{[1.37563]}\end{array}$ & $\begin{array}{c}-0.416671 \\
(0.0 .0809) \\
{[-1.81372]}\end{array}$ & $\begin{array}{c}0.128959 \\
(0.1131) \\
{[1.63783]}\end{array}$ & $\begin{array}{c}12700.39 \\
(0.3543) \\
{[0.94251]}\end{array}$ & $\begin{array}{c}0.360608 \\
(0.2450) \\
{[1.18854]}\end{array}$ & $\begin{array}{c}0.012067 \\
(0.3291) \\
{[0.99388]}\end{array}$ \\
\hline $\mathrm{D}($ LOGFDFCT(-2)) & $\begin{array}{c}0.067432 \\
(0.4757) \\
{[0.72341]}\end{array}$ & $\begin{array}{c}-0.074841 \\
(0.6623) \\
{[-0.44164]}\end{array}$ & $\begin{array}{c}0.057355 \\
(0.3322) \\
{[0.98751]}\end{array}$ & $\begin{array}{c}9166.959 \\
(0.3646) \\
{[0.92225]}\end{array}$ & $\begin{array}{c}0.059784 \\
(0.7914) \\
{[0.26713]}\end{array}$ & $\begin{array}{c}0.013994 \\
(0.1298) \\
{[1.56250]}\end{array}$ \\
\hline D(LOG_REER(-1)) & $\begin{array}{c}0.903643 \\
(0.0154) \\
{[2.40951]}\end{array}$ & $\begin{array}{c}0.240107 \\
(0.6734) \\
{[0.42607]}\end{array}$ & $\begin{array}{c}-0.659941 \\
(0.0020) \\
{[-3.41685]}\end{array}$ & $\begin{array}{c}60897.34 \\
(0.0764) \\
{[1.84235]}\end{array}$ & $\begin{array}{c}-0.452464 \\
(0.0312) \\
{[-0.60795]}\end{array}$ & $\begin{array}{c}-0.052659 \\
(0.8809) \\
{[-1.76809]}\end{array}$ \\
\hline D(LOG_REER(-2)) & $\begin{array}{c}0.569717 \\
(0.0121) \\
{[4.68977]}\end{array}$ & $\begin{array}{c}0.139274 \\
(0.8224) \\
{[0.22672]}\end{array}$ & $\begin{array}{c}-0.416344 \\
(0.0583) \\
{[-1.97744]}\end{array}$ & $\begin{array}{c}15236.59 \\
(0.6758) \\
{[0.42285]}\end{array}$ & $\begin{array}{c}1.843924 \\
(0.1812) \\
{[2.27279]}\end{array}$ & $\begin{array}{c}-0.004912 \\
(0.0020) \\
{[-0.15129]}\end{array}$ \\
\hline D(LOG_VAT(-1)) & $\begin{array}{r}0.0051101 \\
(0.0000) \\
{[10.2606]}\end{array}$ & $\begin{array}{c}-1.06 \mathrm{E}-05 \\
(0.1430) \\
{[-1.50878]}\end{array}$ & $\begin{array}{c}7.98 \mathrm{E}-07 \\
(0.7425) \\
{[0.33195]}\end{array}$ & $\begin{array}{c}-0.381285 \\
(0.3621) \\
{[-0.92702]}\end{array}$ & $\begin{array}{c}-1.27 \mathrm{E}-05 \\
(0.5957) \\
{[-1.37235]}\end{array}$ & $\begin{array}{c}1.27 \mathrm{E}-06 \\
(0.0690) \\
{[3.41638]}\end{array}$ \\
\hline D(LOG_VAT(-2)) & $\begin{array}{c}0.013417 \\
(0.3107) \\
{[-1.03308]}\end{array}$ & $\begin{array}{l}9.91 \mathrm{E}-06 \\
(0.5594) \\
{[0.54176]}\end{array}$ & $\begin{array}{l}1.84 \mathrm{E}-06 \\
(0.7710) \\
{[0.29407]}\end{array}$ & $\begin{array}{c}-2.915089 \\
(0.0113) \\
{[-2.71793]}\end{array}$ & $\begin{array}{c}-1.30 \mathrm{E}-05 \\
(0.0049) \\
{[-0.53690]}\end{array}$ & $\begin{array}{l}1.83 \mathrm{E}-06 \\
(0.8086) \\
{[1.89418]}\end{array}$ \\
\hline
\end{tabular}




\begin{tabular}{|c|c|c|c|c|c|c|}
\hline D(LOG_BRDM(-1) & $\begin{array}{c}0.110879 \\
(0.0137) \\
{[5.23791]}\end{array}$ & $\begin{array}{l}0.002240 \\
(0.9890) \\
{[0.01396]}\end{array}$ & $\begin{array}{c}-0.047151 \\
(0.3987) \\
{[-0.85744]}\end{array}$ & $\begin{array}{l}-37426.33 \\
(0.0005) \\
{[-3.97692]}\end{array}$ & $\begin{array}{l}-0.649723 \\
(0.0363) \\
{[-3.06627]}\end{array}$ & $\begin{array}{l}0.002074 \\
(0.5182) \\
{[0.24456]}\end{array}$ \\
\hline D(LOG_BRDM(-2) & $\begin{array}{c}0.448129 \\
(0.0213) \\
{[2.44389]}\end{array}$ & $\begin{array}{l}0.141644 \\
(0.4779) \\
{[0.84069]}\end{array}$ & $\begin{array}{l}0.032010 \\
(0.5839) \\
{[0.55432]}\end{array}$ & $\begin{array}{l}-22686.63 \\
(0.0297) \\
{[-2.29562]}\end{array}$ & $\begin{array}{l}-0.490119 \\
(0.2217) \\
{[-2.20264]}\end{array}$ & $\begin{array}{l}0.005830 \\
(0.0137) \\
{[0.65475]}\end{array}$ \\
\hline D(LOGIMPT(-1)) & $\begin{array}{l}0.083851 \\
(0.0024) \\
{[3.35460]}\end{array}$ & $\begin{array}{l}-3.991811 \\
(0.2439) \\
{[-1.19129]}\end{array}$ & $\begin{array}{l}0.079852 \\
(0.9451) \\
{[0.06953]}\end{array}$ & $\begin{array}{l}262472.6 \\
(0.1929) \\
{[1.33544]}\end{array}$ & $\begin{array}{l}5.536158 \\
(0.8019) \\
{[1.25101]}\end{array}$ & $\begin{array}{l}0.466898 \\
(0.9202) \\
{[2.63648]}\end{array}$ \\
\hline D(LOGIMPT(-2)) & $\begin{array}{c}0.229548 \\
(0.0977) \\
{[1.71555]}\end{array}$ & $\begin{array}{c}2.207293 \\
(0.4663) \\
{[0.70586]}\end{array}$ & $\begin{array}{l}0.789953 \\
(0.4674) \\
{[0.73705]}\end{array}$ & $\begin{array}{c}-265582.7 \\
(0.1591) \\
{[-1.44793]}\end{array}$ & $\begin{array}{c}-1.046248 \\
(0.9437) \\
{[-0.25334]}\end{array}$ & $\begin{array}{l}-0.016710 \\
(0.1084) \\
{[-0.10111]}\end{array}$ \\
\hline $\mathrm{C}$ & $\begin{array}{c}-32.27105 \\
(0.4787) \\
{[-0.71842]}\end{array}$ & $\begin{array}{c}-0.013052 \\
(0.8381) \\
{[-0.20636]}\end{array}$ & $\begin{array}{l}0.051512 \\
(0.0248) \\
{[2.37638]}\end{array}$ & $\begin{array}{r}-1132.712 \\
(0.07625) \\
{[-0.30534]}\end{array}$ & $\begin{array}{c}-0.005949 \\
(0.0835) \\
{[-0.07122]}\end{array}$ & $\begin{array}{c}0.005549 \\
(0.1184) \\
{[1.66026]}\end{array}$ \\
\hline $\begin{array}{l}\text { R-squared } \\
\text { Adj. R-squared } \\
\text { F-statistic } \\
\text { Probability }\end{array}$ & $\begin{array}{l}0.87103 \\
0.803856 \\
13.44390 \\
0.000031\end{array}$ & $\begin{array}{r}0.781131 \\
0.675749 \\
7.412413 \\
0.00006\end{array}$ & $\begin{array}{r}0.487577 \\
0.240855 \\
1.976218 \\
0.65568\end{array}$ & $\begin{array}{r}0.681365 \\
0.527948 \\
4.441266 \\
0.00005\end{array}$ & $\begin{array}{r}0.585464 \\
0.385873 \\
2.933317 \\
0.00088\end{array}$ & $\begin{array}{l}0.722090 \\
0.588281 \\
5.396435 \\
0.00011\end{array}$ \\
\hline
\end{tabular}

Source: Own calculation from e-view 7.1

Note: Figures in () are the p-value, and Figures in [] are the $t$-value with the corresponding parameters *Shows that $p$-value is significant at 5\% level of significance. ECOT-represent the error correction term

\subsection{Short Run causality from Wald Coefficient Restriction Test Result}

In the framework of VECM, short-run causality is obtained by conducting the Wald coefficient restriction test. In the short run also there is causality running from lagged variables of Value added tax to price level from 2004:Q1 to 2014:Q4. The reason is that coefficients of VAT from Wald coefficients are different from zero indicating the causality from VAT to inflation in Ethiopia in the short run. The result of the Wald coefficient restriction test has shown in table 4.8 below. Concerning other variables, the result found short-run causality running from Broad Money (BRDM), import (IMPT), and real effective exchange (REER) to inflation (CPI) in Ethiopia for the periods under investigation. This result is similar to the granger causality test and also the long-run causality test. The fiscal deficit does not cause inflation in the short run. The null hypothesis of Wald coefficient restriction cannot be rejected implying no causality running from FDFCT to inflation in the short run. The possible justification may be that it takes time for the government to plan to monetize the fiscal deficit, and the government may also solve the problem in a way that does not affect aggregate price level at least in the short run.

Table 4.8: the results of Wald tests on Coefficient Restrictions

Source: Own computation from e-view 7.1

\begin{tabular}{|l|l|l|l|l|l|}
\hline The Null Hypothesis of the Wald Test & $\begin{array}{l}\text { Statistics of Chi- } \\
\text { square }\end{array}$ & $\begin{array}{l}\text { P- } \\
\text { Value }\end{array}$ & $\begin{array}{c}\text { F- } \\
\text { statistics }\end{array}$ & $\begin{array}{c}\text { P- } \\
\text { Value }\end{array}$ & Decision \\
\hline $\begin{array}{l}\text { Coefficients of Lagged LOGCPI are } \\
\text { equal to Zero }\end{array}$ & 66.1979 & 0.0000 & 33.09896 & 0.0000 & Reject \\
\hline $\begin{array}{l}\text { Coefficients of lagged LOG FDFCT } \\
\text { variables are equal to Zero }\end{array}$ & 2.064050 & 0.3563 & 1.032025 & 0.3699 & $\begin{array}{l}\text { Do not } \\
\text { Reject }\end{array}$ \\
\hline $\begin{array}{l}\text { Coefficients of lagged LOG REER } \\
\text { Variables are equal to Zero }\end{array}$ & 12.27875 & 0.0022 & 6.139373 & 0.0063 & Reject \\
\hline $\begin{array}{l}\text { Coefficients of Lagged LOG VAT } \\
\text { Variables are equal to Zero }\end{array}$ & 129.6697 & 0.0000 & 64.83483 & 0.0000 & Reject \\
\hline $\begin{array}{l}\text { Coefficients of lagged LOG BRDM } \\
\text { Variables are equal to Zero }\end{array}$ & 9.525848 & 0.0085 & 4.762924 & 0.0169 & Reject \\
\hline $\begin{array}{l}\text { Coefficients of lagged LOG IMPT } \\
\text { variables are equal to Zero }\end{array}$ & 11.27283 & 0.0090 & 5.636415 & 0.0036 & Reject \\
\hline
\end{tabular}




\subsection{Model Stability Diagnostic}

\section{a. CUSUM and the CUSUM of squares (CUSUMSQ) Tests}

The existence of Stability is considered as a strength of the model in econometric analysis. The stability in this study is established to strengthen the analysis of the study. The stability of the parameters was examined through plots from one-step recursive residuals in a graphical estimate (see figure 4.1) and also from the cumulative sum of square (CUSUM) and CUSUMSQ at a 5\% percent level of Significance. The null hypothesis of parameter stability does not reject as the plots of the recursive residual bounds within $95 \%$ critical values. This implies that the parameters and coefficients study is stable for the period examined. Figure 4.3: Model Stability from the CUSUM and CUSUMQ statistics test results for model stability tests.

The cumulative sum of recursive residuals (CUSUM) and the CUSUM of squares (CUSUMSQ) tests was applied to test for parameter constancy. The plots of the CUSUM and CUSUM of squares statistics results indicate the absence of any instability of the coefficients during the investigated period because the plots of the two statistics are confined within the $5 \%$ critical bounds about the parameter stability.

\section{Fig1: The cumulative sum of recursive residuals and the CUSUM of square tests}

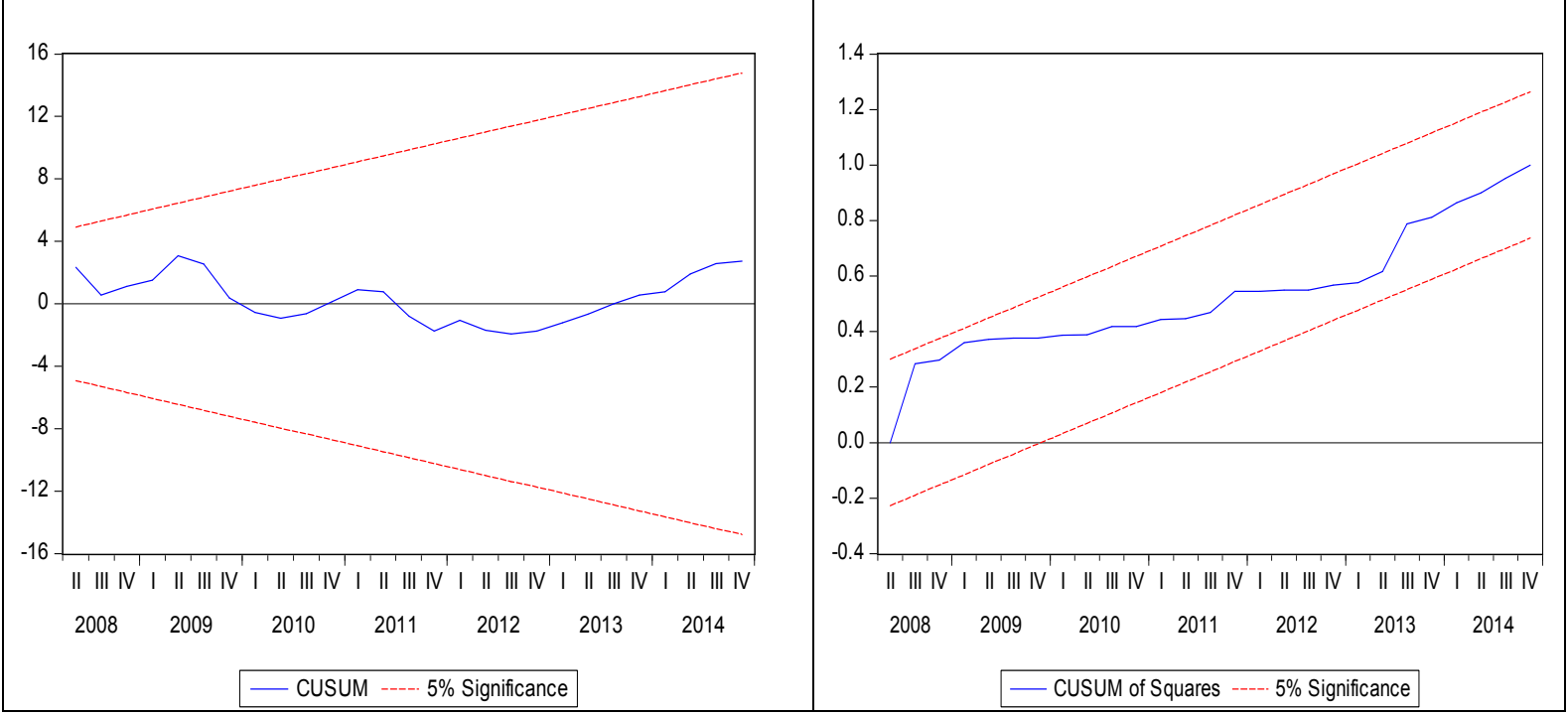

Source: Own computation from e-view 7.1

b. The Jerque Bera Normality Test

This study also uses the Jerque Bera normality test due to its power fullness and popularity in multivariate empirical work to check the normality of the study model. Jerque Bera histogram normality test is developed due to Jerque and Bera (1987). Jerque Bera test is calculated as follows concerning the number of observations as follows:

$$
J B=\frac{\mathrm{n}-\mathrm{K}}{6}\left(\mathrm{~s}^{2}+\frac{1}{4}(\mathrm{c}-3)^{2}\right)
$$

Where, JB is Jerque Bera test statistics, and, $\mathrm{n}$ is the number of observations. $\mathrm{K}$ is the number of explanatory variables.

In Jerque Bera normality test, the null hypothesis (Ho) is that time-series data is normally distributed while the alternative hypothesis (HA) is that they are not normally distributed. The rejection of Ho in Jerque Bera depends on the probability attached to Jerque Bera test. If the probability attached to the test should be less than 0.05 for the Ho of Jerque Bera to be rejected. If the probability 0.467468 is greater than 0.05 the Ho cannot be rejected indicating the model is normal. 
Fig 2: The Histogram Jerque Bera Normality Test

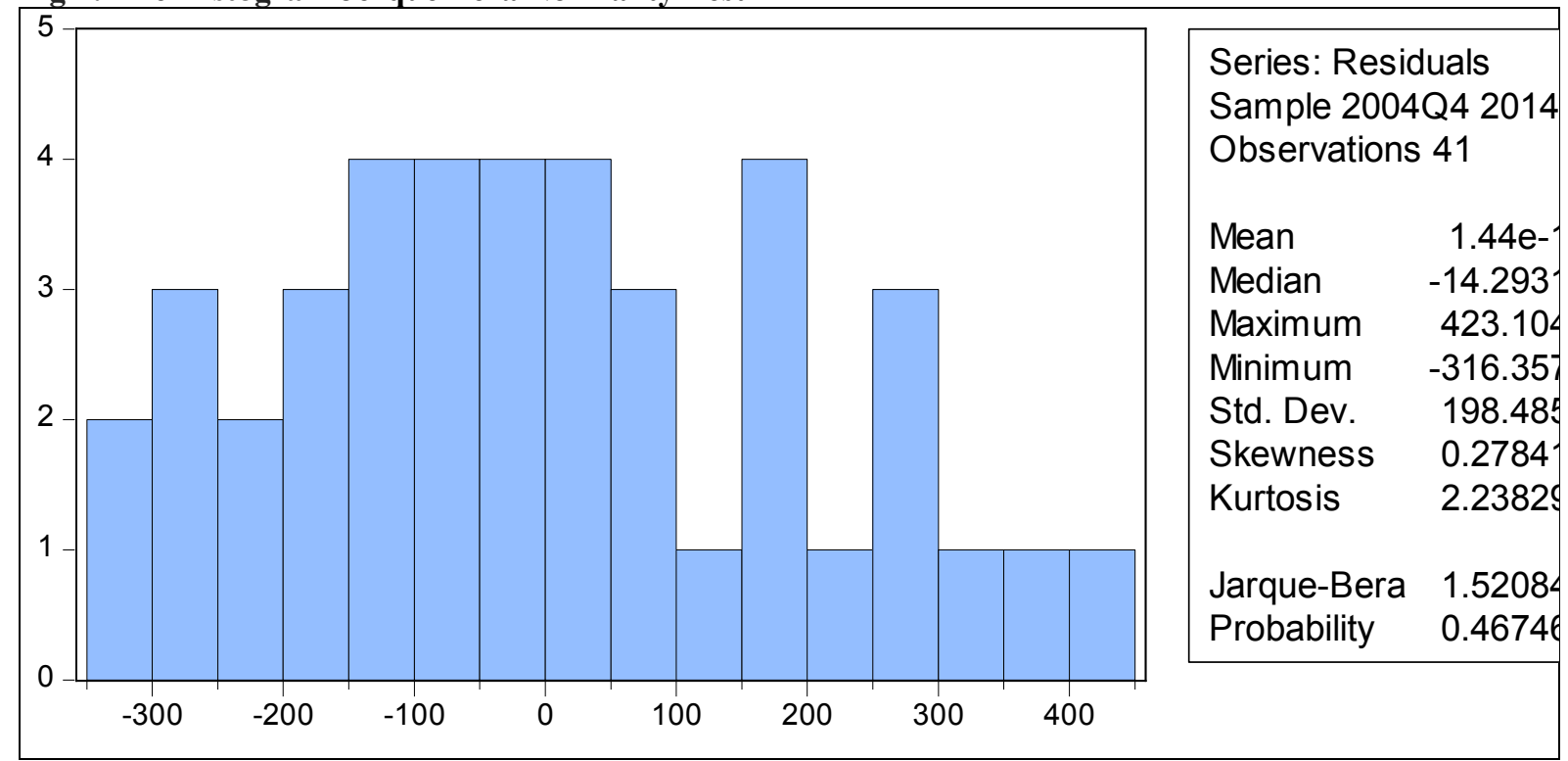

Source: Own computation from e-view 7.1

C. Breusch-Godfrey Serial Correlation LM Test

Testing for autocorrelation in a time series is among the common task. This test was developed due to the work of Breusch and Godfrey (1978). Breusch-Godfrey Serial Correlation LM test is the most widely applied test of serial correlation when compared to the Durbin Watson test of serial correlation. This study conducted the BreuschGodfrey Serial Correlation LM test as it is well applicable in higher orders of serial correlation. Two cases should be considered for time being in this study. For the case of transformed LM test, the LM serial autocorrelation test is given by:

$$
L M=n-\frac{\mathrm{K}}{\mathrm{m}} \times \frac{R^{2}}{1-R^{2}}
$$

Where $\mathrm{m}$ is the number of restriction, $\mathrm{K}$ is the number of estimated coefficients

In this study, there is a suspect that that $u t$ is first-order serially correlated and thus the LM test equation to be applied is

$u t=\rho 1+u t-1+\varepsilon t$

Here, $N\left(0, \delta^{2}\right)$ and $t=2004 Q 1$ to $2014 Q$, where, $\varepsilon t$ represent first-order error term serially correlated.

The Null hypothesis of the Breusch-Godfrey Serial Correlation LM test is that H0: $\rho 1=0$ meaning that there is no serial correlation while the alternative is that HA: $\rho 1 \neq 0$. The alternative hypothesis says that there is serial correlation in the model which is not desirable. The decision to reject or not reject the null hypothesis depends on the LM test statistics and the probability attached to it. As depicted in Table 9 below, the probability of LM test 0.27585 is more than $5 \%$. Thus, we do not reject the null hypothesis and this implies that the model is free from any serial correlation which the desired result and the model are good and can be used in forecasting and further analysis.

\section{Table 9: Breusch-Godfrey Serial Correlation LM Test}

Breusch-Godfrey Serial Correlation LM Test

\begin{tabular}{lllc}
\hline \hline F-statistic & & & \\
Obs*R-squared & 0.837950 & Prob. F(2,25) & 0.4444 \\
\hline \hline
\end{tabular}

Source: Own computation from e-view 7.1

Finally, all tests indicated that the model is stable, normal, and free from any serial correlations. Thus, it is now possible and safe to draw a conclusion and prescribe policy to policymakers.

\section{Conclusion and Policy Implication}

This study scrutinized the casual relationships between VAT and inflation in Ethiopia using Granger causality analysis of quarterly time series data over the period 2004Q1 -2014Q4. Inflation is a major challenge to the Ethiopian economy. Thus, dealing with the relationship between value-added tax and aggregate price level in Ethiopia is, unquestionable, important since it offers a baseline to counterfeiting a long-term elucidation. 
The conclusion from the Pairwise Granger causality analysis indicates that there is a unidirectional causal relationship running from VAT to general price level in Ethiopia. Besides, both in the long and short-run VAT cause inflation from the period of 2004Q1 to 2014Q4. In both periods the causality is unidirectional and runs from VAT to inflation. The other serious problem here is that it becomes very difficult to draw a line between intermediate and final outputs even if they are exempted from the VAT. The conclusion inferred from this study is consistent with the conclusion drawn by Maries and Al well (2013) and Ajakaiye (1999), who concluded also that VAT strongly pushes up the price level. Thus, Value Added tax despite its noteworthy contribution to the national revenue is not free from strong inflationary consequences in Ethiopia.

Besides, the Granger causality test is concerned; all variables cause inflation except the real effective exchange rate which is attributed to the depreciation of the real effective exchange rate that pushes up inflationary pressure in Ethiopia. The causality is unidirectional and runs from explanatory variables to inflation. The conclusion is drawn here also coincides with what Vicente (2007), Gossaye, (2015), Irmana (2013), and Ulke and Ergun (2011), Oliver and Michael (2014) concluded in their work.

The finding of the study has shown that VAT is inflationary. Similarly, broad money (simply money supply) is also found to have inflationary consequences. The general policy implication, therefore, is that for effective price control in Ethiopia, both fiscal policy and monetary policy should be well coordinated. The idea is that although value-added tax (VAT) is weaker than broad money when viewed from an elasticity aspect the fact that it positively influences inflation suggests that stability in VAT revenue is necessary to condition for stable prices in Ethiopia. It follows that ensuring fiscal stability seems to be a panacea for sustainable price stability in Ethiopia. In developing countries like Ethiopia, the result from such a study helps to consolidate the benefit of VAT by providing better management in the tax system.

\section{Limitation of the Study}

The availability of data is the major challenge of scholars in developing nations including Ethiopia. For instance, it was intended to include the quarterly growth rate of GDP as an independent variable of the study. But due to the nonexistence of data, it could not be included. Similarly, the producer price index failed to be incorporated due to the unavailability of data for many years from the NBE. The drawback of such measures is that the quality of estimated results could be reduced.

\section{Recommend Supplementary Studies}

Inflation is a complex fundamental macroeconomic problem that affects the life of peoples in day-to-day activities. The causal linkage between VAT and inflation may be affected by several factors in developing countries like Ethiopia. Any countries in the world want to maximize public revenue by intruding consumption taxes like VAT, and at the same time, any economy wants to have single-digit inflation. Thus, further studies may focus on the linkage between the revenue maximization objective of the government and inflation-targeting policies of the government.

\section{Conflict of Interest}

This article is virtuously an intellectual work for academic advancement. It has got no conflict of interest in any form or shape. The author has decided to work on this article to add to the body of knowledge in the field of business and economics.

\section{References}

Abate, M. T. (2011). Ethiopian Tax Accounting: Principles and Practice((New Revised Edition). Addis Abeba, Ethiopia.

Adereti S.A, Adesina J. A and Sanni, M.R. (2011). Value Added Tax and Economic Growth of Nigeria. European Journal of Humanities and Social Sciences, Vol. 10 (No.1 (Special Issue)), 456-471.

Ajakaiye, D. O. (1999). Macroeconomic Effects of VAT in Nigeria: Computable General Equilibrium Analysis. African Economic Research Consortium Research paper No. 92 (pp. 1-38). Nairobi: The African Economic Research Consortium.

Ajisafe, R. A. (1996). “An Empirical Investigation of the Determinants of Inflation in Nigeria. Ife Journal of Economics and Finance, Vol. 3, (No. 1-2,), pp. 65-94.

Alemu, D. (2011). Empirical Analysis of The Contribution of Value added tax For Economic Development and Social Spending in Ethiopia (MSc Thesis). Addis Ababa University, Department of Accounting and Finance.: Addis Ababa.

Aruwa, Suleiman A. S. 82008) 'The Administration and Problems of Value Added Tax in Nigeria' Finance and Accounting Research Monitor, 2(2) available at http://ssm.com/abstract=1418661.

Ashwani, (2014). Determinants of Inflation in India: A Co-Integration Approach. International Journal of Multidisciplinary Consortium, Vol. 1, Issue 1, 1-11 ISSN2349-073X

Begotic Z. and Hassan F. (1993). " Determinants of Value-Added Tax Revenue: A Cross-Sectional Analysis ". World Bank Working Paper-series No.1203.

Carlstrom, C. T., and T. S. Fuerst. (1999). 'Money Growth and Inflation: Does Fiscal Policy Matter?'. Economic 
Commentary Federal Reserve Bank of Cleveland, USA.

Daniel, B. C. (2004). 'Notes on Seigniorage and the Fiscal Theory of the Price Level'.

Denbel Sh.F., Yilkal W.A., and Teshome A. R. (January 2016). The Relationship between Inflation, Money Supply, and Economic growth in Ethiopia: A Cointegration and Causality Analysis. International Journal of Scientific and Research Publications, Volume 6, (Issue 1), 556-565.

Dickey, D.A \& Fuller, W.A. (1979). Distribution of the Estimators of Autoregressive Time Series with a Unit Root. Journal of the American Statistical Association, 74: 427-431.

Everton Dockery Vincent N. Ezeabasili Wilson E. Herbert. (September 2012). The Relationship between Fiscal Deficits and Inflation: Econometric Evidence for Nigeria. Economics and Finance Review, Vol. 2(7), pp. 17 - 30.

The Federal Democratic Republic of Ethiopia. (2008). Value added tax (Amended) proclamation No. 609/2008. Federal Negarit Gazeta,15th Year No. 6,25th December, pp. 4371-4382, Addis Ababa, Ethiopia.

The Federal Democratic Republic of Ethiopia. (2002, July 4). Value Added Tax Proclamation No. 285/2002. Federal Negarit Gazeta,8th Year No. 33, pp. 1832-1865, Addis Ababa, Ethiopia.

Gossaye, T. (2015). Effectiveness of Devaluation in Achieving Internal and External Balance: The Case of Ethiopia. Unpublished Masters thesis, Addis Ababa University, Addis Ababa.

Granger, C.W.J. (1986). Developments in the Study of Cointegrated Economic Variables. Oxford Bulletin of Economics and Statistics, 3 (48), pp. 213-228.

Gyebi Francis and Boafo Godfried K. (2013). Macro-Economic determinants of Inflation In Ghana from 1990 2009. International Journal of Business and Social Research (IJBSR), Volume -3, (No.-6,).

Imrana Asad Nisar Ahmad Zakir Hussain. (2013). Impact of Real Effective Exchange Rate on Inflation on Pakistan. Asian Economic and Financial Review, 2 (8), 983-990.

Jalata, D. M. (2014). The Role of Value Added Tax on Economic Growth of Ethiopia. Science, Technology and Arts Research Journal, Vol.3 (No.1), 156-161.

Jalata, D. M. (2014). The Value-Added Tax Styles: Which is Adopted by Ethiopia? Journal of Economics and Sustainable Development, 5 (11), 77-82.

Johansen, S. (1991). Estimation and hypothesis testing of cointegration vectors in gaussian vector autoregressive models. 59, 1551-80.

Johansen, S., Juselius, K. (1990). Maximum Likelihood Estimation and Inference on Cointegration: with Applications to the Demand for Money. Oxford Bulletin of Economics and Statistics, 52, 169-210.

Lozano, I. (2008). 'Budget Deficit, Money Growth, and Inflation: Evidence from the Columbian Case. Central Bank of Columbia, Economics Research Department, Banco de la Republica.

Maddala. (1992). Introduction to Econometrics,. New York.: MACMILLAN Publishing Company.

Marius Ikpe and Alwell Nteegah. (2013). Value Added tax and price stability in Nigeria. European Journal of Government and Economics, 2 (2), 137-147.

Maurice, Laure. (1954). Direction Generale Des imports, Director of French Tax Authority. pp. http://enwiki.org/wiki/value-added-tax retrieved, 22/2/2016.

Michael, K, and Ben, L. (2007). The Value-Added Tax: Its Causes and Consequences. Working Paper 183. IMF.

Newey, W., and West, K. (1994). Automatic Lag Selection in Covariance Matrix Estimation. Review of Economic Studies, Vol 61, pp. pp. 631-653.

Olatunji, O. C. (2009). A Review of Value Added Tax( VAT) in Nigeria. International Business Management, 3 (4), 61-68.

Olorunfemi Sola, Adeleke Peter. (2013). Money Supply and Inflation in Nigeria: Implications for National Development. Modern Economy, http://dx.doi.org/10.4236/me.2013.43018 Published Online March 2013 (http://www.scirp.org/journal/me), 162-170.

Phillips, P., and P. Perron. (1988). Testing for a unit root in time series regression, Biometrika, 75, 335-346.

Sargent, T., and N. Wallace. (1981). 'Some Unpleasant Monetarist Arithmetic. Federal Reserve Bank of Minneapolis Quarterly, Vol. 5, ( No. 3), pp. 1-17.

Simon Tareke, Yibrah Hagos, Abiy Kassa. (2013). Problems and Prospects of Value-Added Tax (VAT) Implementation in Tigrai Regional State. Vol. $1 \mid$ No. 1, Vol. 1 (| No. 1), 1-16.

Tripathi R., Agarwa A., Sinhand S. (2011). The effect of value-added taxes on Indian society. Journal of Accounting and Taxation, Vol. 3 (2), pp. 32-39.

Ulke V. and Ergun U. (2011). Econometric Analysis of Import and Inflation Relationship in Turkey between 1995 and 2010. Journal of Economic and Social Studies, Volume 1 (Number 2), 69- 81.

Vicente, C. (2007). Exchange rate and Consumer Prices in Mozambique: A Cointegration Approach. Conference Paper no. 40, (pp. 1-23).

Vogelvang, B. (2005). Econometrics. In Theory and Applications with EViews. Pearson Education Limited.

Yesegat, W. A. (2008). Value Added Tax Administration in Ethiopia: A Reflection of Problems. eJournal of Tax Research, 6 (2), 145-168. 